\title{
A conversation with Mary-Claire King
}

$\mathbf{F}$ genetics than Mary-Claire King of the University of Washington. King (Figure 1) was the first to show that breast cancer is inherited in some families as a result of mutations in the gene that she named BRCA1. She had already changed our view of evolution when she demonstrated during her PhD work that the protein-coding DNA sequences of humans and chimpanzees are 99\% identical. She's also been a tireless social justice warrior, protesting wars, fighting the patenting of genes, and pioneering research in using genomic tools to aid in the investigation of human rights abuses. A condensed version of our conversation is presented here.

JCI: What were you like as a child?

Mary-Claire King: I grew up in Chicago. My Dad was born in 1890, so was almost 60 when I was born. From his early 60 s, he was ill with what we ultimately realized were late-onset effects of the 1918 influenza epidemic, a severe Parkinson-like syndrome. So from the time I was about six years old, he was always home with my brother and me.

One consequence of his being home was that we could watch the Cubs and White Sox on TV. My dad had relatively little formal education, likewise my mom, but both were very bright. My dad in particular was very fond of story problems. For example, as we were watching a Cubs game, he would say, "Ernie Banks is batting .277 and he'll probably have three at bats this game. What's he going to have to bat to bring his average above .280?" I was six, so I would think and think and say, "I don't know." He would say, "You're right. What else do you need to know?" Then we'd work through what else. I needed to know how many at bats Ernie Banks had already had in the season. We worked through these really complex problems. Eventually they seemed easy. As a result, nothing about arithmetic, algebra, or story problems ever threw me.

JCI: Is that what led you to do a degree in mathematics?

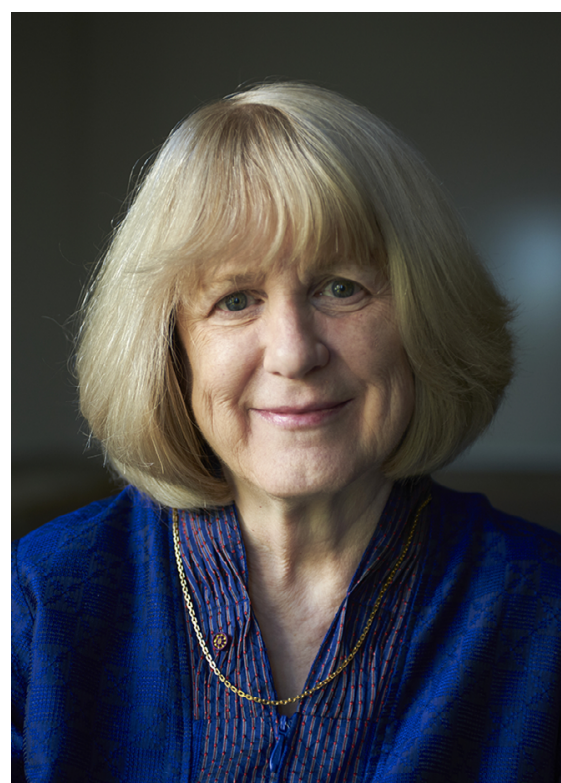

Figure 1. Mary-Claire King in October 2018.

King: I went to a fine public high school, where I had two wonderful female math teachers, one with a $\mathrm{PhD}$; they were my first role models for any women in science. I realized in college that while I was pretty good at math, I wasn't nearly good enough to do it professionally. I went to Berkeley for graduate school thinking to study statistics, which is more applied and I found more tractable. Then I took a genetics course - my first plunge into biology. I absolutely loved it. I transferred to genetics and never looked back.

JCI: During the time you were getting a $\mathrm{PhD}$, you were also quite involved with social justice causes. How did you come to start working with Ralph Nader?

King: This was the '60s in Berkeley. We were all involved in social justice causes: the civil rights movement and subsequently the anti-war movement. One day, on the way to lab, I saw a little $3 \times 5$ card posted on a bulletin board. It said, "Ralph Nader needs a biologist to work on the California Project. He will be coming to investigate who owns California and what they are doing with the land they own." I thought that was interesting, so I called the number and talked with Ralph and ended up working on the California Project.

After the California Project was published, Ralph offered me a job in Washington, DC. Allan Wilson, who was then a friend but not yet my advisor, convinced me not to drop out of graduate school. He said, "If you leave now, you can do good work. There's no question it's righteous work, but with only a bachelor's degree, you'll never set the agenda. If you finish your $\mathrm{PhD}$, you'll have many more opportunities." I countered that none of my experiments worked. He said, "If everybody whose experiments failed stopped doing science, there would be no one left. Let's see if we can figure out a project that is experimentally not too difficult but that takes advantage of the fact that you can write equations." That became the project on human and chimpanzee evolution and the demonstration that we and chimpanzees share $99 \%$ of our coding sequences.

JCI: You moved to Chile after your PhD. What was that time like?

King: We were in Chile in the early 1970s, during the years of the Popular Unity government, the Allende period. It was eye opening to a gringa like me. Beginning in the 1960s, there was an exchange sponsored by the Ford Foundation between the University of California and the Universidad de Chile that allowed for very easy exchange of faculty, postdocs, and graduate students. My then-husband was a field ecologist; Chile was heaven-sent for his work.

I soon realized that when you teach in a place that has few specialists, you end up teaching a bit of everything. I taught genetics and statistics and evolution. But my courses didn't last long, because in September 1973 a military coup overthrew President Allende's government. The universities closed. We tried to protect our students, most successfully, some not.

JCI: Why come back to Berkeley and why do a postdoc after such a stimulating teaching experience?

King: Like many progressive young Americans, we were tempted with the idea of staying, but it soon became clear that wasn't possible. We came back to Berke- 
ley in late 1973 because my then-husband was on the faculty in zoology. The concept of postdoc didn't quite exist then, but there were many jobs available in cancer research, because President Nixon had just launched the war on cancer. One of those jobs was at UCSF with a lovely pediatric oncologist named Nicholas Petrakis who had become interested in breast cancer.

It was clear that breast cancer had a major familial component. Herodotus, the ancient Greek historian, wrote about it. There was also excellent epidemiology beginning in the early 20th century that made it clear that critical time points in a woman's life had a major influence on her subsequent breast cancer risk: in particular her age of menarche and the age at which she had her first child. The longer the interval between menarche and first childbirth, the higher the subsequent breast cancer risk. That interval is longer in places where girls are well nourished, and therefore enter puberty fairly young, and where young women are educated, and often postpone childbearing: breast cancer is uniquely a cancer of prosperity. Overlaying that, there were families that were very severely affected with breast cancer. It seemed to me that breast cancer was likely due to some factors that were genetic and some that were not.

I decided to probe the inherited genetic component. In the 1970 s, no one was postulating inherited risk for a complex trait like breast cancer. I was very lucky because the National Cancer Institute (NCI) was carrying out an epidemiological study of breast cancer risk associated with oral contraceptives. I asked if I could add some questions to the NCI questionnaire about family history, and the investigators very kindly said yes. I soon had data from 1,500 women with breast cancer, beautifully ascertained, beautifully interviewed, and 1,500 cancer-free women for comparison. The women had provided detailed information about their own breast cancers and about other cancers in their families. There was no molecular genetics in this study, of course; it was just interviews. No one was picking up a pipette, least of all me. Instead, I used the information from these women to develop a maximum likelihood model, a straightforward statistical model to test all possible explanations for clustering of breast cancer in families.
It was straightforward to show that breast cancer did cluster in families to a greater degree than one would expect by chance. But why? Was the clustering because of a polygenic effect? Was it because of a recessive genetic effect, like for Tay-Sachs or cystic fibrosis? Was it because of a dominant genetic effect like for Huntington's disease? Or was it some combination? I had enough information to be able to formally test those models. The best-fitting model, by far, was the hypothesis that the clustering in families could be explained by the existence of one or more dominantly inherited genes that would move the lifetime risk of breast cancer from $8 \%$ to $80 \%$. The gene was hypothetical. This was only mathematics. It was just a prediction. The way it would play out in reality was unknown.

JCI: During this time, you transitioned from postdoc to faculty. You've mentioned before that you got the job via affirmative action.

King: It's absolutely true. I am a child of affirmative action, and I'm proud to be one. At UC Berkeley in those days, there was a rule that spouses could not be faculty members in the same department. My then-husband was in zoology, so that precluded my even being considered for a position there. My degree had been in genetics at Berkeley, and there was another exclusion that a department could not hire its own graduate students, so that precluded genetics as well. A job opened up in the School of Public Health in the field of epidemiology. I thought, shucks, geneticists and epidemiologists have a lot to say to each other.

In 1975, there were brand-new affirmative action guidelines in the University of California system that included two critical elements. One was that every search committee had to include a woman as a member. I think there was also an agreement that every search committee had to include a student. The committee for this new position satisfied both rules by including a woman student, an epidemiologist-in-training named Catherine Schaefer - who is now one of the chief epidemiologists at Kaiser Permanente. The other critical element of the affirmative action guidelines was that if a woman or a person from an underrepresented minority applied for a faculty position, that person either needed to be interviewed or a detailed explanation had to be provided indicating why they were not appropriate even for an interview. I learned later that the search committee thought it would be easier to interview me than to write the explanation.

My PhD project on human and chimpanzee evolution had just appeared on the cover of Science, so it was hard to dismiss me as a flake. My talk was scheduled for a small classroom that held maybe 30 people. It was anticipated that 20 or 30 people would attend. Of course, I had been at Berkeley my whole graduate career and had been involved in the antiwar movement and the civil rights movement and the labor organizing movement and what was then the nascent feminist movement. I had many friends all across campus. The little room was filled half an hour before my talk. People were out in the hall and on the stairwells. The elevators jammed because there were so many people trying to get in. It was just totally fabulous. My talk had to be moved to the auditorium. It went well.

After I was offered the position, the senior gentleman faculty member who had chaired the committee said to me, "Cathy Schaefer was a bulldog, she wouldn't let go.” He also said, "I just want you to know that we are scratching the bottom of the barrel in hiring you. It's very clear you don't know any epidemiology." I said, "I'm going to remind you later of your views." Indeed, when I was awarded tenure three years later (half the usual time), I reminded him. He said, "I never said that. I absolutely didn't say that. I totally wanted to hire you. Remember how I said that you did a great job and you made your case?" He had honestly forgotten.

The reality is that I never would have gotten an interview if there hadn't been an affirmative action policy. I needed a shot, and affirmative action gave it to me. So yes, I'm a child of affirmative action and enormously grateful for it.

JCI: You captured one aspect of this time in your life in a storytelling festival called The Moth. I don't want to ruin the story for those who haven't heard it yet (https://www.youtube.com/ watch?v=tOP5pUIYhv4). You absolutely excel in your storytelling capacity and your ability to find humor in retelling a tale of real adversity. Have you always had this gift of communication? 
King: I work very hard on my teaching. I have also spent enough of my life working in languages other than English to be very conscious of how to phrase ideas and be clear, even with the limited words at my command. I've had to do this in Spanish and in French. I have enormous admiration for people who work in a second language.

JCI: Getting back to your research after establishing your lab, you spent the next few years identifying $B R C A$. When you were able to reduce the space where the causative gene was to chromosome 17, did you have champagne?

King: We actually reduced the location of the gene on chromosome 17 to about a megabase. Of course, we didn't know then the size of the region we'd pinpointed. There was no physical map of the human genome. By 1990, I knew we had done the genetics properly, I knew we had done the math properly. But what I didn't know was how generalizable the result would be. Were my families unique in some way I didn't know? I was way too hesitant to have champagne.

A very fine geneticist named Gilbert Lenoir was interested in the same question and studied a different set of families in France. I sent him all the probes that I had made. He repeated exactly my experiments in his families and got the same result. When that happened, I believed it. Then we had champagne.

But we didn't know what the gene was. We had no idea of its sequence, let alone its function. But we knew it was findable. In early 1991, neither of us had the remotest idea of how exhausting it would be without a genome sequence. It stimulated a four-year race, ultimately involving hundreds of investigators and perhaps 15 sizeable groups.

JCI: Would you term this time as competitive or extremely competitive?

King: It was extremely competitive. One of my collaborators, an athletic guy in one of our sister labs, said, "I run marathons. I once thought I'd be an Olympic athlete. This is as intense as that." I never had that experience, but this was as competitive as it gets. You just had to keep your eye on the prize. Everyone was using exactly the same strategy, and it took four years. Myriad did indeed clone BRCA1 first. They made critical mistakes in their sequence - but they were the first to publish an amino acid sequence of BRCA1.
Everyone involved knew what to do. Myriad cloned the gene first because they had vastly more sophisticated equipment, so could move much more quickly through thousands of DNA fragments.

JCI: Ultimately Myriad was granted a patent on $B R C A$, which was revoked by the Supreme Court in 2013 after the American Civil Liberties Union (ACLU) filed suit. Were you involved at all in supporting the view that genes should not be patented?

King: I was able to provide historical background and detail, to help get the facts right for a whole variety of amicus briefs. Nina Totenberg [correspondent for National Public Radio] called after the decision. She said, "The Supreme Court decision has just come out: it's 9 to 0." I said, "Which way?" She said, "Oh, in favor of the ACLU position." I said, "Wow." She said, "Surely you have a longer comment than that." I said, "I'm as high as the flag on the fourth of July." She said, "That'll do."

By the next day, BRCA1 and BRCA2 sequencing were in the public domain and commercially available. You can't help asking yourself, suppose it had been available years earlier, how many women could we have saved who died because the testing was too expensive?

JCI: How did you get started in the realm of using genomic tools to aid in the investigation of human rights abuses?

King: In the early 1980s, I was doing a sort of mini-sabbatical, commuting back forth from Berkeley to Stanford, where Luigi Luca Cavalli-Sforza very kindly agreed to teach me molecular genetics. He pointed out my work could never proceed just doing research at the mathematical level.

The Grandmothers of the Plaza de Mayo (the "Abuelas") had organized themselves in 1977 in Buenos Aires to demand the return of their children who had been murdered and of their grandchildren, about whom they had increasingly good anecdotal evidence of at least some survivors. They asked the Committee on Scientific Freedom and Responsibility of the American Association of Advancement of Science (AAAS), the people who publish Science, to recommend to them a geneticist who could help them in their search. They correctly realized that if they could identify a child on the basis of genes in the grandparents, even with the parents missing and presumed dead, then they would know who that child was.

The AAAS suggested that they talk to Dr. Cavalli-Sforza, who was both a brilliant population geneticist and molecular geneticist. They asked him to work out the mathematics of grandpaternity testing. It was a simple application of Bayesian statistics. I was visiting his lab at the time, so several of us worked out the statistics. We published a paper on what we called the "index of grandpaternity," describing how to extend paternity testing to grandparents. The statistics was straightforward, but of course the approach was constrained by the biological tools of the time.

The grandmothers asked Luca to come to Buenos Aires to put grandpaternity testing into practice. Luca said to me, "I'm not doing this. You, however, are perfectly set up for it. You've taught in Spanish; you know Latin America; you obviously know the genetics. Most important, you are the age of the murdered daughters of these women, and your daughter Emily is the age of their kidnapped grandchildren. You'd be perfect." I went in June 1984 for what I thought would be one symbolic trip of solidarity. It became a 30-year collaboration.

JCI: What do you see for the future of your lab in the next 10 years?

King: Our focus in breast cancer is to try to solve the questions facing the many remaining "unsolved" families. We think that noncoding regulatory mutations are likely to hold the answers, just like in my studies of evolution 50 years ago.

At the same time, we're working now to solve congenital disorders in real time, so that parents of severely affected children can use pregestational diagnosis to have a healthy next pregnancy. We're also increasingly interested in the genetics of severe mental illness such as schizophrenia and bipolar disorder. Genetics is a useful way of thinking, and genomics offers fabulous tools. I hope to apply them to as many complex conditions as I can.

JCI: What would you do if you were not a scientist?

King: I would open a daycare for the children of my lab where the kids would learn story problems while their parents do experiments.

\section{Ushma S. Neill}

